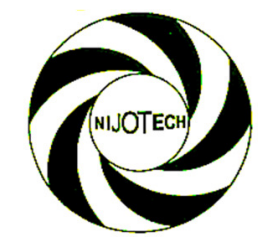

Nigerian Journal of Technology (NIJOTECH)

Vol. 34 No. 2, April 2015, pp. 406 - 413

CopyrightC Faculty of Engineering,

University of Nigeria, Nsukka, ISSN: 111 15-8443 www.nijotech.com

http://dx.doi.org/10.4314/njt.v34i2.27

\title{
SELECTION OF BIOSORBENTS FOR BIOSORPTION OF THREE HEAVY METALS IN A FLOW-BATCH REACTOR USING REMOVAL EFFICIENCY AS PARAMETER
}

\author{
I. C. Nwidi ${ }^{1}$ and J. C. Agunwamba ${ }^{2}$ \\ 1,2 DEPARTMENT OF CIVIL ENGINEERING, UNIVERSITY OF NIGERIA, NSUKKA. NIGERIA \\ E-mail addresses: 1 chineke_nwidi@yahoo.com, 2 nwambaagu@yahoo.com
}

\begin{abstract}
Within the last three decades, the use of low cost biosorbents like bacteria, fungi, algae and some agricultural byproducts have been investigated for their biosorption capacities. In this paper, the biosorptions of three heavy metals (zinc, copper and manganese) from aqueous wastewater solution by five microorganisms (Bacillus circulans, Pseudomonas aeruginosa, Staphylococcus xylosus, Streptomyces rimosus and Saccharomyces sp.(Yeast) were investigated using a combined flow and batch processes. The biosorbents were air-dried without subjecting them to oven heat. Factors affecting biosorption capacity also known as metal uptake capacity, such as solution $\mathrm{pH}$, initial ion concentration of heavy metals, mass of biosorbent and contact time were investigated. The removal efficiencies of the individual microbes were also calculated. The maximum biosorption capacities for the three heavy metals occurred at $\mathrm{pH}$ between 5.5 to 6.5. The biosorption of zinc ion by Staphylococcus xylosus yielded the highest removal efficiency of $94 \%$. Also, the biosorption of copper and managense ions by Bacillus circulans produced highest removal efficiencies of $97 \%$ and $\mathbf{9 0 \%}$ respectively. Initial ion concentrations of heavy metals and mass of biosorbents increase with biosorption capacity. Furthermore, Langmuir isotherm better described equilibrium biosorption of copper by Pseudomonas aeruginosa, Staphylococcus xylosus and Saccharomyces sp. (Yeast) with linear regression coefficient of correlation, $\mathrm{R}^{2}$ of $0.8646,0.9820$ and 0.9902 , Freudlinch isotherm better described the biosorption of copper by Bacillus circulans and Streptomyces rimosus with linear regression coefficient of correlation of 0.7233 and 0.9290 respectively. Lastly, Langmuir isotherm better described the biosorption of manganese by Pseudomonas aeruginosa and Streptomyces rimosus with linear regression coefficient of correlation, $\mathrm{R}^{2}$ of 0.9394 and 0.9880 respectively. On the other hand, Freudlinc isotherm better described the biosorption of Manganese by Bacillus circulans, Staphylococcus xylosus and Saccharomyces sp (Yeast) with linear regression coefficient of correlation, $\mathrm{R}^{2}$ of $0.7891,0.9753$ and 0.7915 respectively.
\end{abstract}

Keywords: Biosorption capacity, Removal Efficiency, Equilibrium isotherms.

\section{INTRODUCTION}

Pollution from industries interacts naturally with biological systems. It seeps into any biological entity within the range of exposure. The most problematic contaminants include heavy metals, pesticides and other organic compounds which can be toxic to wildlife and humans in small concentration[1] Consequently, heavy metals are on the forefront of academic and regulatory concern, since millions of gallons of water containing toxic heavy metals are generated annually from several metal processing industries and discharged into the environment.
Metals discharged into water bodies are not biodegraded but undergoes chemical or microbial transformations, creating large impact on the environment and public health [2]. Therefore, awareness is rapidly growing worldwide and one of its offshoots is treatment and removal of heavy metals from such effluent to permissible limits before discharging into natural streams and rivers. Towards this direction, several conventional wastewater technologies were succinctly developed and are in use at large scale, to reduce hazardous compound concentration in wastewater from higher to lower 
level [3]. Application of such traditional treatments requires enormous cost and continuous input of chemicals which makes them unsustainable and uneconomical. Hence, easy, effective, economical and eco-friendly techniques are required for fine-tuning of wastewater treatment [4].

The search for new technologies involving the removal of toxic metals from wastewaters has directed attention to biosorption, based on metal binding capacities of various biological materials. Biosorption can be defined as the ability of biological materials to accumulate heavy metals from wastewater through mediated or physico-chemical pathways of uptake [5]. Algae, bacteria, fungi and yeast have proved to be potential metal biosorbents [6]. The biosorption process involves a solid phase (sorbent or biosorbent) and liquid phase (solvent, usually water containing a dissolved species to be sorbed. Due to higher affinity of sorbent for the sorbate species, the latter is attracted and bound there by different mechanisms. The process continues until equilibrium is established between the amount of solid-bound sorbate species and its proportion remaining in the solution. The degree of sorbent affinity for sorbate determines its distribution between the solid and liquid phases. Biosorption is a physico-chemical process that occurs naturally in certain biomass which allows it to passively concentrate and bind contaminants onto its cellular structure [7]. Biosorption typically involves a combination of active and passive mechanisms, starting with the diffusion of the metal ion to the surface of the microbial cell $[8,9]$. The ability of microorganisms to interact with and accumulate a variety of metal ions has been well documented [10]. However, there are significant variations in metal uptake capacity among different genera, different species, and also different strains within a species [11]. The literature shows that previous researchers have examined basic and applied aspects of heavy metal biosorption by variety of cellbiomass sources. This includes molds [12], algae $[13,14]$, bacteria $[15,16,17,18,19]$ and fungi $[20,21]$. A review on the application of microbial biofilms to accumulate heavy metals in large-scale operations suggested that their use was limited to low metal concentrations due to waste-stream toxicity [22]. Bacteria make excellent biosorbents because of their high surface-to-volume ratios [23]. Metal binding behaviour has been evaluated on the basis of bacterial cell, gram reaction for viable cells [24] and cell walls and envelopes [25]. Gram-positive bacteria are particularly suitable for metal binding [26, 27]. Sorption of metals to activated sludge solids has been found to conform to the Langmuir and Freundlich isotherms [24]. In a separate study on the removal of heavy metals with sulfides produced by the sulfate reducing bacteria, it was observed that the rate of metal removal was greater than the rate of sulfide production [28]. Moreso, biosorption utilizes the ability of biological materials to accumulate heavy metals from aqueous solutions by either metabolically mediated or purely physico-chemical pathways of uptake [5]. The biological materials that have been investigated for heavy metal uptake include fungi [29], bacteria [30], yeast [2], micro-algae [31] and macroalgae [32]. Many of these materials are available in large quantities either as industrial waste by-products or from the natural sources.

\section{METHODOLOGY}

In this study, the materials used are microorganisms comprising of gram positive, gram negative bacteria and algae which were grown on nutrient broth. The microbes were obtained from Department of Microbiology University of Nigeria, Nsukka while heavy metal solutions were prepared by dissolving metal copper nitrate, manganese sulphate and zinc chloride respectively $\left(\mathrm{Cu}\left(\mathrm{NO}_{3}\right)_{2} \cdot 3 \mathrm{H}_{2} \mathrm{O}, \mathrm{MnSO}_{4} \cdot 4 \mathrm{H}_{2} \mathrm{O}\right.$ and $\mathrm{ZnCl}_{2}$ ) in wastewater to the required concentrations. The biosorbents that were used are: Staphylococcus xylosus, Bacillus circulans. Pseudomonas aeruginosa, Streptomyces rimosus and Yeast (Saccharomyces cerevisiae.)

\subsection{Effect of Contact Time on Biosorption Capacity}

Wastewater reservoir was filled with a mixture of wastewater from University of Nigeria, Nsukka wastewater stabilization pond and zinc chloride to obtain $50 \mathrm{mg} / \mathrm{l}$ concentration of $\mathrm{Zn}^{2+}$ in the solution. $2.5 \mathrm{~g}$ of biosorbents were introduced into the treatment units. The treatment units have baffles to enhance mixing of the wastewater with the biosorbent. The hob at the exit of the treatment unit has a sieve (in this case, whatman filter paper) to limit the quantity of biosorbents that leave the treatment units. The flow into the treatment units and out of the batch reactor/reservoir is controlled by flow controls as shown above. 


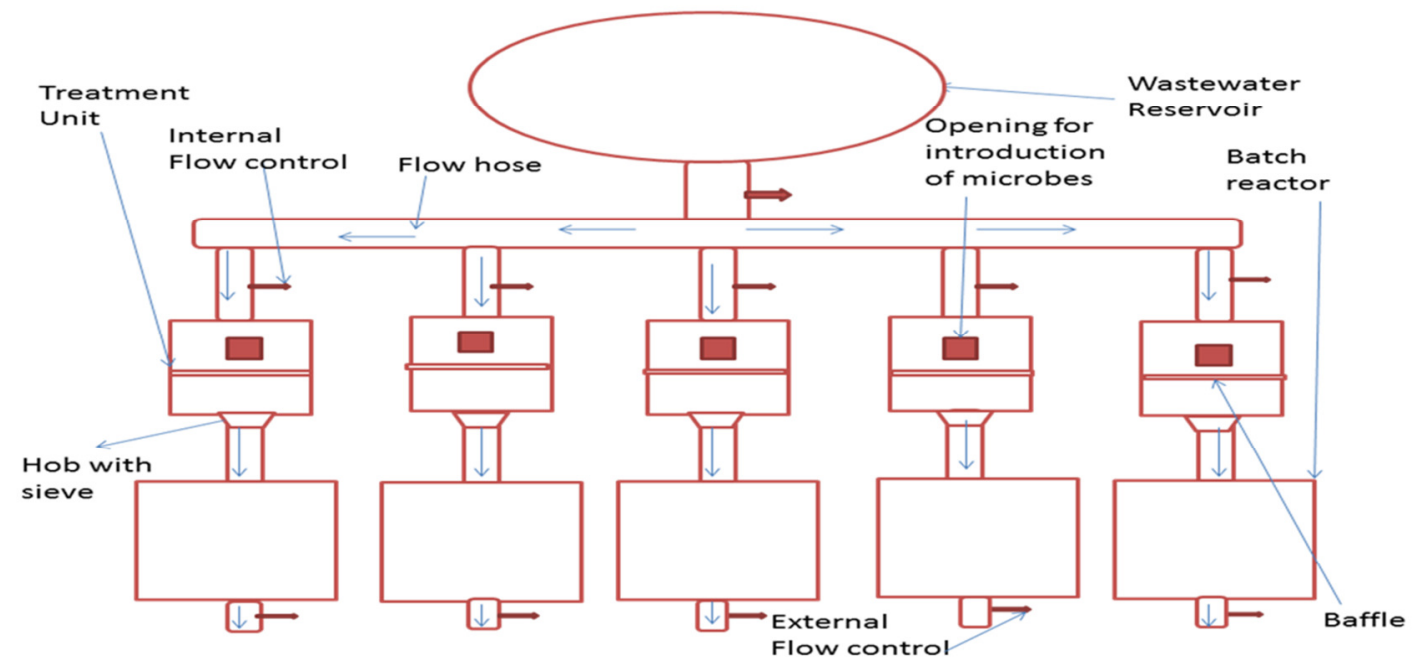

Figure A: Biosorption Pilot Treatment Plant

During the 3-day period of operation, the reactor was monitored for 30 minutes, 2 hours, 24 hours, 48 hours and 72 hours respectively for metal ion concentration of the effluent solution, biosorption capacity (q) and removal efficiency. The biosorption capacity or metal uptake rate was calculated using the following mass balance equation:

$$
q_{t}=\left(C_{0}-C_{t}\right) \frac{V}{M}
$$

Where $\mathrm{q}_{\mathrm{t}}(\mathrm{mg} / \mathrm{g})$; is the biosorption capacity or metal uptake rate at time $\mathrm{t}_{\mathrm{o}}(\mathrm{mg} / \mathrm{l})$ and $\mathrm{C}_{\mathrm{t}}(\mathrm{mg} / \mathrm{l})$ are the initial metal ion concentration and metal ion concentrations at time $\mathrm{t}$ in the solution, respectively; $V(\mathrm{l})$ is the solution volume; and $\mathrm{M}(\mathrm{g})$ is the mass of biosorbent.The $\mathrm{pH}$ of both reactors was kept constant with the aid of a buffer, $0.1 \mathrm{~m} \mathrm{HCl}$ and $0.1 \mathrm{~m} \mathrm{NaOH}$. Room temperature was assumed throughout the experiments as temperature range of $20-35^{\circ} \mathrm{C}$ has no effect on biosorption processes of microorganisms [33]. The same experiment was repeated for $\mathrm{Cu}^{2+}$ and $\mathrm{Mn}^{2+}$.

\subsection{Effect of Initial Metal Ion Concentration on Biosorption Capacity}

By keeping all other parameters such as $\mathrm{pH}$, mass of biosorbents $(2.5 \mathrm{~g})$, temperature (room temperature) and contact time constant (3 days), the same experiments as above were repeated with initial metal ion concentration of $100 \mathrm{mg} / \mathrm{l}, 200 \mathrm{mg} / \mathrm{l}, 300 \mathrm{mg} / \mathrm{l}$, $400 \mathrm{mg} / \mathrm{l}$ and $500 \mathrm{mg} / \mathrm{l}$ of $\mathrm{Zn}^{2+}$ respectively with the sole aim of obtaining the concentration of zinc ion at 25 minutes detention time and at equilibrium. The metal concentration of both the influents and effluents were obtained using a HI83200 Multiparameter spectrophotometer. The amount of metal adsorbed by each biosorbent was calculated using the following balance equation:

$$
q_{e}=\left(C_{0}-C_{t}\right) \frac{V}{M}
$$

Where $\mathrm{q}_{\mathrm{e}}$ is the equilibrium biosorption capacity or metal uptake $(\mathrm{mg} / \mathrm{g}) ; \mathrm{C}_{\mathrm{o}}$ and $\mathrm{C}_{\mathrm{t}}$ are the initial metal ion concentration and metal ion concentrations at time $\mathrm{t}$ in the solution $(\mathrm{mg} / \mathrm{l})$, respectively; $V$ is the solution volume (l); and $\mathrm{M}$ is the mass of biosorbent (g). The same experiment was performed for copper and manganese ions.

\subsection{Effect of pH on Biosorption Capacity}

This was achieved by keeping constant, the initial zinc ion concentration at $200 \mathrm{mg} / \mathrm{l}$, contact time at 3 -days, room temperature and mass of biosorbents at $2.5 \mathrm{~g}$, the $\mathrm{pH}$ of the solution was varied from 2, 4, 6, 8 and 10 respectively. The $\mathrm{pH}$ of the solution was equilibrated by using $0.1 \mathrm{M} \mathrm{HCl}$ and $0.1 \mathrm{M} \mathrm{NaOH}$. The equilibrium concentrations were obtained and metal uptake rates calculated respectively. The $\mathrm{pH}$ of the solution was read with a $\mathrm{pH}$ meter. The same experiment was performed for copper and manganese ions.

\subsection{Effect of Mass of Biosorbent on Biosorption Capacity}

This was also achieved by keeping constant, the initial zinc ion concentration at $200 \mathrm{mg} / \mathrm{l}$, contact time at 3 days, room temperature and $\mathrm{pH}$ at 6 , mass of biosorbents were varied from $1 \mathrm{~g}, 2 \mathrm{~g}, 3 \mathrm{~g}, 4 \mathrm{~g}$, and $5 \mathrm{~g}$ respectively. The equilibrium concentrations were obtained and metal uptake capacities calculated 
respectively. The same experiment was performed for copper and manganese ions respectively.

\subsection{Removal Efficiency (RE\%) and Average Relative Error (ARE\%)}

Also, the performance of microorganism biosorption in terms of its removal efficiency, (RE\%) was estimated using the following equation:

$$
R E \%=\frac{C_{0}-C_{t}}{C_{0}} \times 100
$$

Where $C_{t}$ is the metal ion concentration at time $t, C_{0}$ is initial metal ion concentration both measured in $\mathrm{mg} / \mathrm{l}$ [34].

2.5.1 The Langmuir model [35] Sorption model is used for the estimation of maximum sorbate sorption by the biosorbent

$$
\frac{1}{q}=\frac{1}{q_{\max }}+\frac{1}{b q_{\max } C_{f}}
$$

$\mathrm{q}(\mathrm{mg} / \mathrm{g})$, and $\mathrm{q}_{\max }(\mathrm{mg} / \mathrm{g})$, are the equilibrium and maximum adsorption capacities of adsorbent $\mathrm{b}(\mathrm{L} / \mathrm{mg})$ is the Langmuir constant is related to the energy of adsorption and $\mathrm{C}_{\mathrm{f}}\left(\mathrm{mgL}^{-1}\right)$ is the equilibrium concentration of the metal ion

2.5.2 The Freundlich model [36]. The linearised for of Freundlinch model is given by'

$$
\ln q=\ln K+\frac{1}{n} \ln C_{f}
$$

Where, $K(\mathrm{mg} / \mathrm{g})$ is the Freundlich constant related to adsorption capacity of adsorbent and $\mathrm{n}$ is the dimensionless Freundlich exponent related to adsorption intensity, $\mathrm{C}_{\mathrm{f}}$ and $\mathrm{q}$ as defined above.

The linear regression coefficient of correlations were calculated using equation 6 . Whereas $x$ represents the abscissas while y represents the ordinates.

$$
R=\sqrt{\frac{\left(n \sum x y-\sum x \sum y\right)^{2}}{\left(n \sum x^{2}-\left(\sum x\right)^{2}\right)\left(n \sum y^{2}-\left(\sum y\right)^{2}\right)}}
$$

\section{RESULTS AND DISCUSSIONS}

The results of effect of contact time, initial sorbate ion concentration, solution $\mathrm{pH}$ and mass of biosorbent against biosorption capacity of the three heavy metals (zinc, copper and manganese) under study are as presented below: Figures 1-3 are chats showing the variation of biosorption capacity with time, Figures 46 are chats representing variation of biosorption with initial sorbate ion concentration, Figures $7-9$ represent variation of biosorption capacity with $\mathrm{pH}$ while Figures $10-12$ represent variation of biosorption capacity with mass of biosorbents.

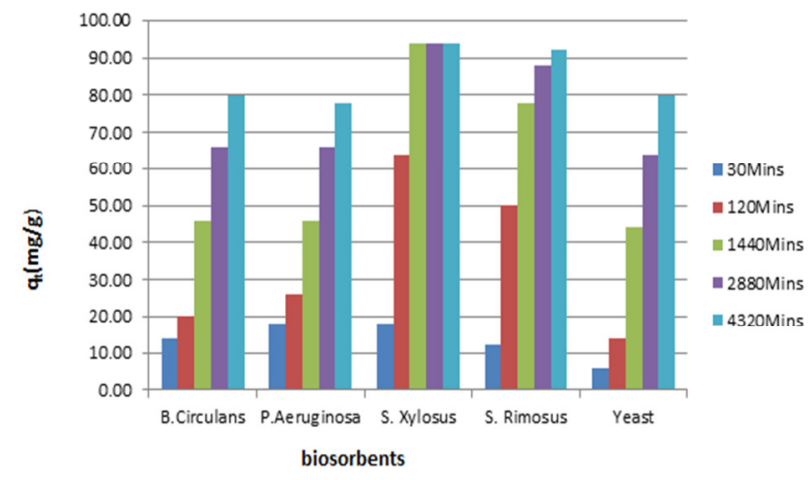

Figure 1: Variation of $q_{t}$ with $t$ (Effect of Contact Time on Biosorption of Zinc)

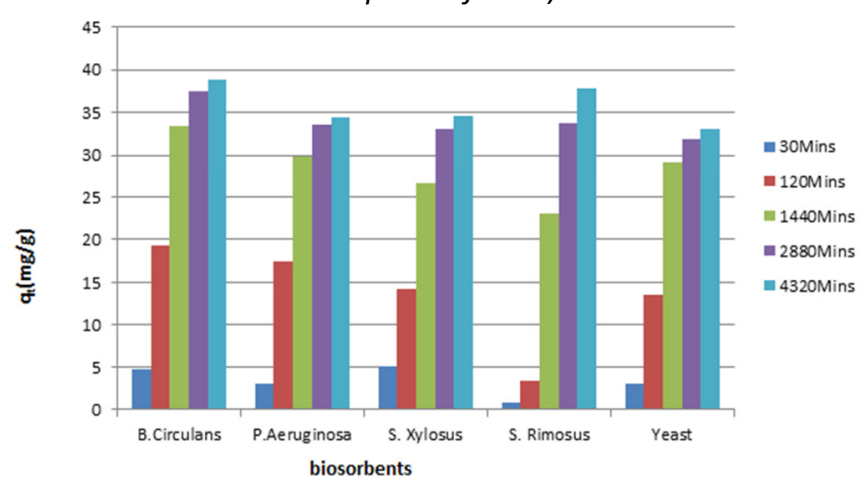

Figure 2: Variation of $q_{t}$ with $t$ (Effect of Contact Time on Biosorption of Copper)

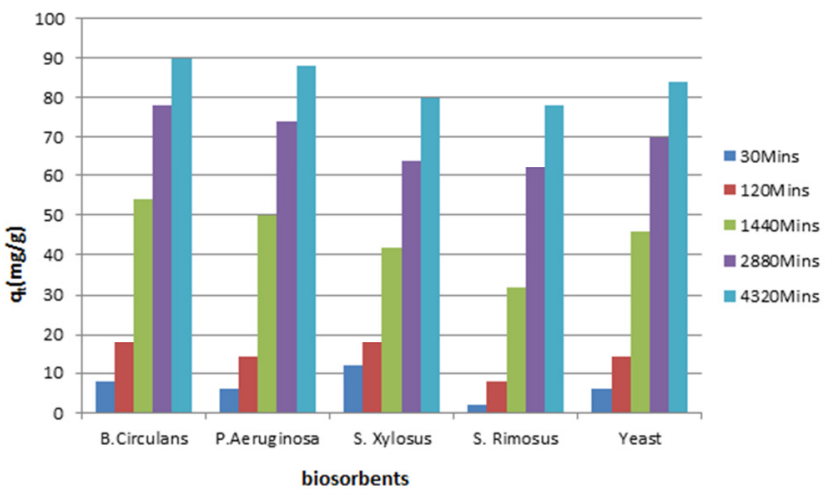

Figure 3: Variation of $q_{t}$ with $t$ (Effect of Contact Time on Biosorption of Manganese)

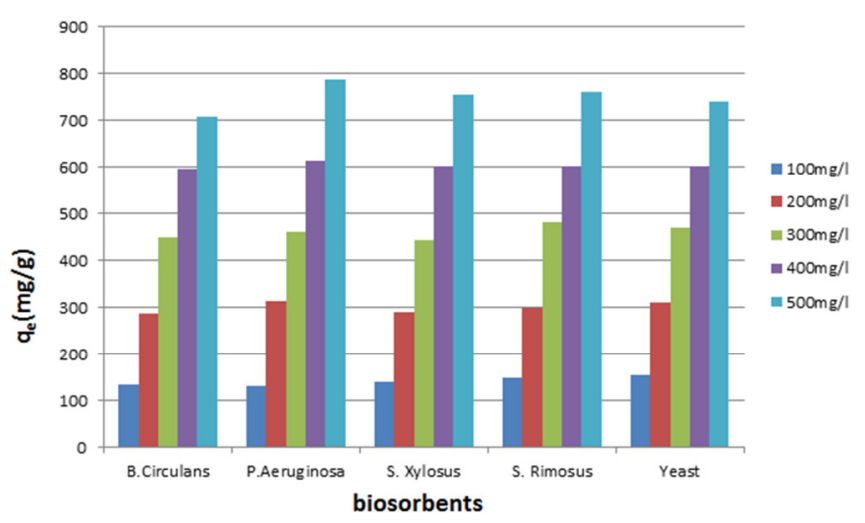

Figure 4: Variation of $q_{t}$ with $C_{0}$ (Effect of Initial Sorbate Concentration on Biosorption of Zinc) 


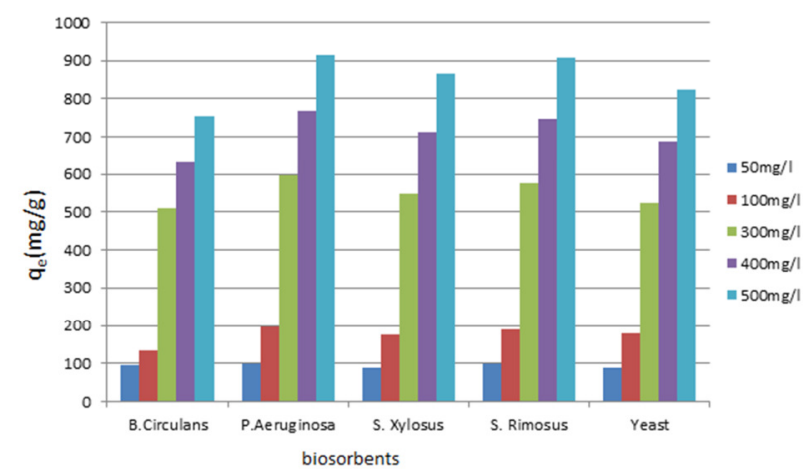

Figure 5: Variation of $q_{t}$ with $C_{0}$ (Effect of Initial Sorbate

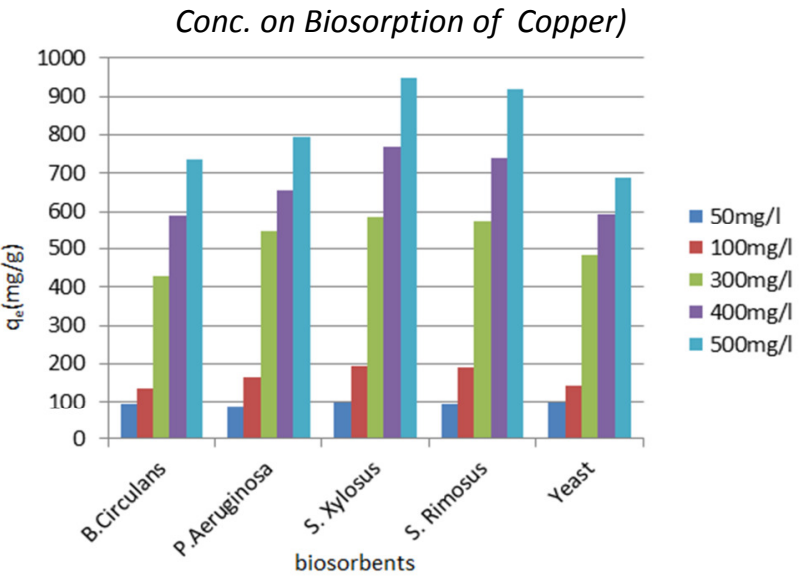

Figure 6: Variation of $q_{t}$ with $C_{0}$ (Effect of Initial Sorbate Conc. on Biosorption of Manganese)

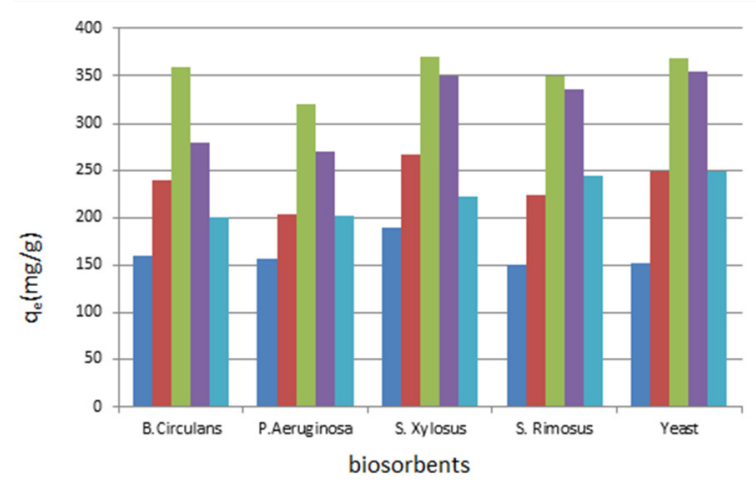

Figure 7: Variation of $q_{t}$ with $\mathrm{pH}$ (Effect of $\mathrm{pH}$ of the solution on Biosorption of Zinc)

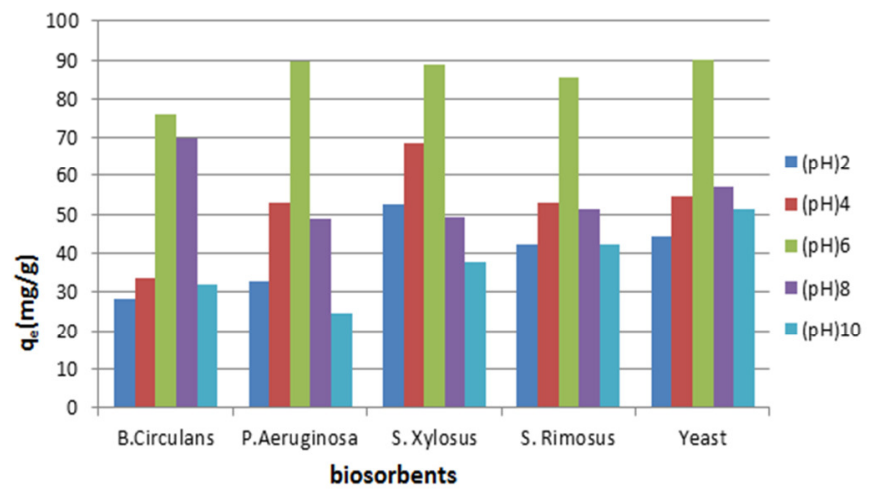

Figure 8: Variation of $q_{t}$ with $\mathrm{pH}$ (Effect of $\mathrm{pH}$ of the solution on Biosorption of Coppe)r

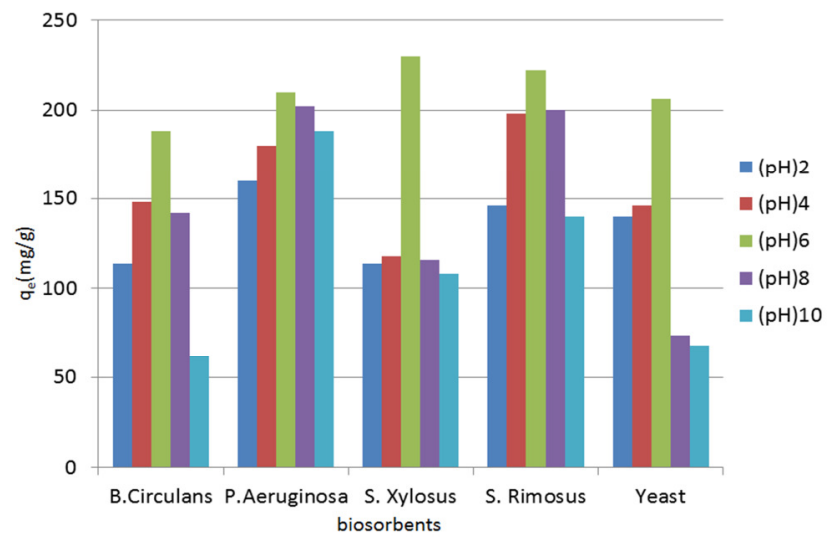

Figure 9: Variation of $q_{t}$ with $\mathrm{pH}$ (Effect of $\mathrm{pH}$ of the solution on Biosorption of Manganese)

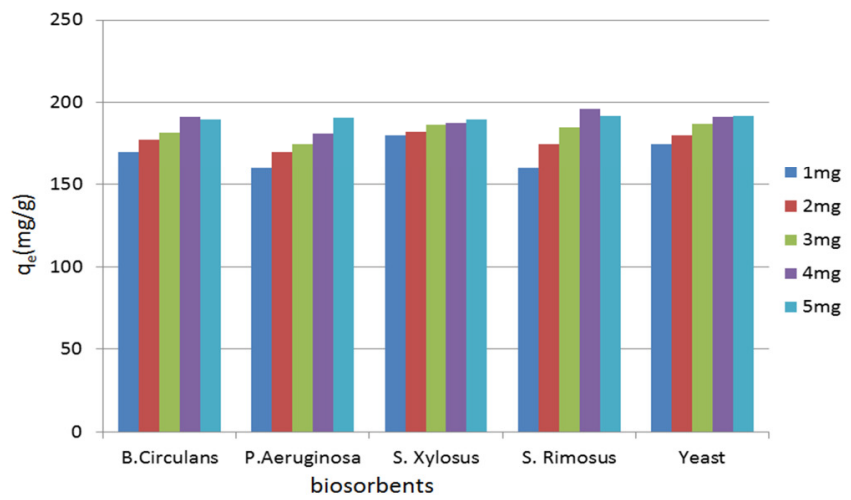

Figure 10: Variation of $q_{t}$ with $M$ (Effect of mass of biosorbent on Biosorption of Zinc)

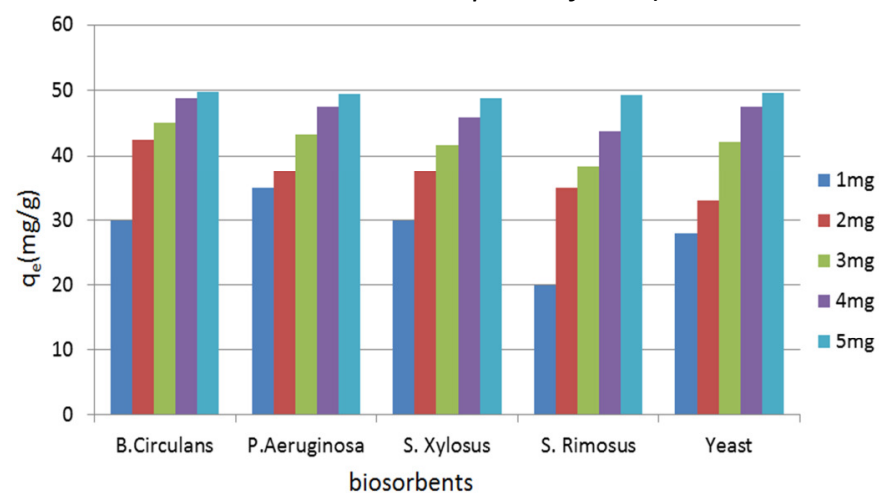

Figure 11: Variation of $q_{t}$ with $M$ (Effect of mass of biosorbent on Biosorption of Copper)

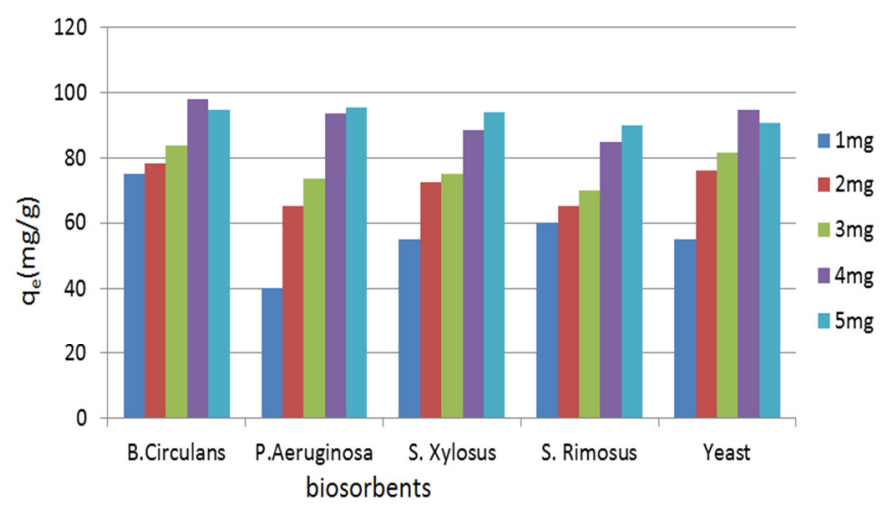

Figure 12: Variation of $q_{t}$ with $M$ (Effect of mass of biosorbent on Biosorption of Manganese) 


\section{DISCUSSION}

Figures 1 - 3 represent the effect of contact time on biosorption of zinc, copper and manganese respectively by the five aforementioned microorganisms. On the average, the biosorption capacity or metal uptake increases with time. The equilibrium biosorption capacity was attained within 72 hours. The most remarkable is the biosorption of zinc by Staphylococcus xylosus which reached equilibrium state within 24 hours as shown on Figure 1. Also, the chats show that there were high rates of biosorption within the first few hours, which later declined until equilibriums were established. Figures 4 - 6 represent the effect of initial sorbate concentration on biosorption capacity. As expected, increase in initial metal ion concentration led to increase bisorption capacity of the biosorbents. Figures 7 - 9 represent the effect of $\mathrm{pH}$ on biosorption capacity. $\mathrm{pH}$ is a very important factor in biosorption experiment. The charts show that maximum biosorption capacity occurred within $\mathrm{pH}$ 6. Figures 10 - 12 represent the effect of mass of biosorbent on biosorption capacity. Increase in mass of biosorbent led to increase in equilibrium biosorption capacity. Using values of linear regression coefficients of regression $\left(\mathrm{R}^{2}\right)$, the high coefficient of correlation for Bacillus circulans\& Pseudomonas aeruginosa suggests that the two biosorbents adsorbed $\mathrm{Zn}^{2+}\left(\mathrm{R}^{2}=0.9731\right.$, $0.9726)$ and $\mathrm{Mn}^{2+}\left(\mathrm{R}^{2}=0.9412,0.9535\right)$ gradually throughout the period of examnations until equilibrium concentrations were attained. In other words, there were consistency in the sequence of assimilation by different sites. Also, the low value of linear regression coefficient of correlation for the biosorption of copper $\left(\mathrm{R}^{2}=0.7212\right)$ by Bacillus circulans suggests that the sites involved in biosorption assimmilated zinc and copper at different rates and that accounted for the production of different curves by the plots and consequently low values of linear regression coefficient of correlationsthe. Also, the low values of linear regression coefficient of correlation respectively and trend of biosorption of $\mathrm{Zn}^{2+}$ and $\mathrm{Cu}^{2+}$ by Staphylococcus xylosus $\left(\mathrm{R}^{2}=0.5410\right.$ and 0.8257$)$ suggests that the linear graph cannot be used to analyse biosorption curve. The high coefficient of correlation for biosorption of Staphylococcus xylosus $\left(\mathrm{R}^{2}=0.9844\right)$ suggests that the adsorption rate was gradual and steady until equilibrium concentration was attained. Streptomyces rimosus has high linear regression cofficient of correlation for the biosorption of $\mathrm{Cu}^{2+}$ and $\mathrm{Mn}^{2+}\left(\mathrm{R}^{2}=0.9208\right.$ and 0.9614$)$ and low linear regression coefficient of correlation on the biosorption of $\mathrm{Zn}^{2+}\left(\mathrm{R}^{2}=0.7074\right)$. Also, the Yeast recorded low coefficient of correlation for the biosorption of $\mathrm{Cu}^{2+}\left(\mathrm{R}^{2}=0.7320\right)$ and high coefficient of correlation for the biosorption of $\mathrm{Zn}^{2+}$ and $\mathrm{Mn}^{2+}\left(\mathrm{R}^{2}\right.$ $=0.9658$ and 0.9614$)$. Table 1 below shows different removal efficicncies of the biosorbents on the three selected heavy metal

Table 1: Removal Efficiency of the Five Biosorbents

\begin{tabular}{|c|c|c|c|}
\hline S/NO & BIOSORBENT & HEAVY METAL & $\%$ ADSORBED \\
\hline \multirow{3}{*}{1} & \multirow{3}{*}{ Bacillus circulans } & Zinc & 80 \\
\hline & & Copper & 97 \\
\hline & & Manganese & 90 \\
\hline \multirow{3}{*}{2} & \multirow{3}{*}{$\begin{array}{l}\text { Pseudomonas } \\
\text { aeruginosa }\end{array}$} & Zinc & 78 \\
\hline & & Copper & 86 \\
\hline & & Manganese & 88 \\
\hline \multirow{3}{*}{3} & \multirow{3}{*}{$\begin{array}{l}\text { Staphylococcus } \\
\text { xylosus }\end{array}$} & Zinc & 94 \\
\hline & & Copper & 86 \\
\hline & & Manganese & 80 \\
\hline \multirow{3}{*}{4} & \multirow{3}{*}{$\begin{array}{l}\text { Streptomyces } \\
\text { rimosus }\end{array}$} & Zinc & 92 \\
\hline & & Copper & 94 \\
\hline & & Manganese & 78 \\
\hline \multirow{3}{*}{5} & Yeast & Zinc & 80 \\
\hline & (Saccharomyces & Copper & 82 \\
\hline & sp.) & Manganese & 85 \\
\hline
\end{tabular}

From the Table 1, the percentage of heavy metals adsorbed by Bacillus circulans, was highest with copper solution followed by manganese then zinc solutions respectively. The percentage of heavy metals adsorbed by Pseudomonas aeruginosa and Saccharomyces sp.(Yeast) is highest with manganese solution followed by cupper and then zinc solutions respectively. For Staphylococcus xylosus, the percentage of zinc removed was highest followed by copper and manganese respectively but for Streptomyces rimosus, the removal efficiency of Copper is highest followed by zinc and then manganese.

\section{BISORPTION ISOTHERMS}

Two popular isotherms were used to study the biosorption of the selected heavy metals by the five microbes. The two isotherms are Langmuir and Freudlinch isotherms. The results are as shown below Furthermore, Langmuir isotherm better described equilibrium biosorption of copper by Pseudomonas aeruginosa, Staphylococcus xylosus and Saccharomyces sp. (Yeast) with linear regression coefficient of correlation $\mathrm{R}^{2}$ of $0.8646,0.9820$ and 0.9902. But, Freudlinch isotherm better described the biosorption of copper by Bacillus circulans and Streptomyces rimosus with linear regression 
coefficient of correlation of 0.7233 and 0.9290 respectively. Lastly, Langmuir isotherm better described the biosorption of Manganese by Pseudomonas aeruginosa and Streptomyces rimosus with linear regression coefficient of correlation $\mathrm{R}^{2}$ of 0.9394 and 0.9880 respectively. On the other hand, Freudlinc isotherm better described the biosorption of Manganese by Bacillus circulans, Staphylococcus xylosus and Saccharomyces sp (Yeast) with linear regression coefficient of correlation $\mathrm{R}^{2}$ of 0.7891 , 0.9753 and 0.7915 respectively.

Table 2. Summary of Results of Two Biosorption Isotherms

\begin{tabular}{|c|c|c|c|}
\hline $\begin{array}{l}\text { HEAVY } \\
\text { METAL }\end{array}$ & BIOSORBENT & $\begin{array}{l}\text { VALUE OF R² } \\
\text { (LANGMUIR } \\
\text { ISOTHERM) }\end{array}$ & $\begin{array}{l}\text { VALUE OF R } 2 \\
\text { (FREUDLINC } \\
\text { ISOTHERM) }\end{array}$ \\
\hline \multirow{5}{*}{ Zinc } & Bacillus circulans & 0.9783 & 0.9646 \\
\hline & $\begin{array}{l}\text { Pseudomonas } \\
\text { aeruginosa }\end{array}$ & 0.8247 & 0.9046 \\
\hline & $\begin{array}{l}\text { Staphylococcus } \\
\text { xylosus }\end{array}$ & 0.9986 & 0.9999 \\
\hline & $\begin{array}{l}\text { Streptomyces } \\
\text { rimosus }\end{array}$ & 0.9810 & 0.9626 \\
\hline & Yeast & 0.9948 & 0.9856 \\
\hline \multirow{5}{*}{ Copper } & Bacillus circulans & 0.6521 & 0.7233 \\
\hline & $\begin{array}{l}\text { Pseudomonas } \\
\text { aeruginosa }\end{array}$ & 0.8646 & 0.7295 \\
\hline & $\begin{array}{l}\text { Staphylococcus } \\
\text { xylosus }\end{array}$ & 0.9820 & 0.9612 \\
\hline & $\begin{array}{l}\text { Streptomyces } \\
\text { rimosus }\end{array}$ & 0.8713 & 0.9290 \\
\hline & Yeast & 0.9902 & 0.9832 \\
\hline \multirow{5}{*}{$\begin{array}{c}\text { Mangane } \\
\text { se }\end{array}$} & Bacillus circulans & 0.6803 & 0.7891 \\
\hline & $\begin{array}{l}\text { Pseudomonas } \\
\text { aeruginosa }\end{array}$ & 0.9394 & 0.8916 \\
\hline & $\begin{array}{l}\text { Staphylococcus } \\
\text { xylosus }\end{array}$ & 0.9656 & 0.9753 \\
\hline & $\begin{array}{l}\text { Streptomyces } \\
\text { rimosus }\end{array}$ & 0.9880 & 0.9574 \\
\hline & Yeast & 0.6901 & 0.7915 \\
\hline
\end{tabular}

\section{CONCLUSION}

From the biosorption results above, its obvious that out of the five slected microorganisms for the biosorption experiments, Staphylococcus xylosus a gram positive bacterium proved to be the best biosorbent for the removal of zinc ion in wastewaters. Similarly Bacillus circulans has proved to be the best biosorbent for the removal of both copper and manganese ions in wastewaters. These two bisorbents, Staphylococcus xylosus and Bacillus circulans are both gram positive bacteria. The reason why gram-positive bacteria adsorb heavy metals more than gram-negative ones could be attributed to their cell wall arrangenements. A typical gram-positive bacteria contain multiple layered peptidoglycan while gram-negative bacterium cell contains only a single layer of peptidoglycan. On a general note, the high removal efficiencies (see table 1) shown by this study indicate that the five microorganisms under study are good biosorbents of the three heavy metals researched on but on a specific note, Staphylococcus xylosus is recommended for removal of zinc ions while Bacillus circulans is recommended for removal of Copper and Manganese respectively. Moreso, the preference in adsorption of one heavy metal to others exhibited by the five microbes indicates that biosorption depends on available sites and the nature of those sites. The contents of the available sites have a great influence on the adsorption of a specific adsorbate over another.

The result of the bisorption isorthem has proven that none of the two most popular used isotherms can be singled out as the best in describing the biosorption experiments.

\section{REFERENCES}

1. Alleman, James E., Prakasam, T. B. S. (1983) Reflections on seven Decades of Activated Sludge History, Water Pollution Control Federation 37 (2): $151-162$

2. Volesky, B., may, H., Holan Z.,(1993). Cadmium biosorption by $S$. cerevisiae. Biotech. Bioeng 41: 826829.

3. Verma, N., Rehal, R. (1996) Removal of Chromium by Albizia libbeck pods from industrial wastewater. J. ind. Pollut. Control., 12(1) : 55-59.

4. Prakasham, R.S., Sheno Merrie, J., Sheela, R., Saswathi, N., Ramakrishna, S.V. (1999) Biosorption of chromium VI by free and immobilized Rhizopus arrhizus. Environmental Pollution. 104 (3): 421-427.

5. Fourest, E., Roux, J., (1992). Heavy metal biosorption by fungal mycelial by product: mechanisms and influence of pH. Appl. Microbiol. Biotechnol. 37, 399403

6. Kratochvil, D. and B. Volesky (1998) Advances in the biosorption of heavy metals. Trends Biotechnol. 16: 291-300.

7. Ahalya, N., Ramachandra, T. V. and Kanamadi, R. D. (2003) "Biosorption of Heavy Metals" Research Journal of Chemistry And Environment, Vol. 7 (4): 71 $-79$

8. Aksu, A.E., Hiscott, R.N., Yasar, D., Isler, F.I., Marsh, S., (2002). Seismic stratigraphy of Late Quaternary deposits from the southwestern Black Sea shelf: evidence for non-catastrophic variations in sea-level during the last V10 000 years. Mar. Geol. 190, S00253227(02)00343-2.

9. Galceran, M. T., Rubio, R, and Rauret, G. (1990). Assessment of groundwater contamination 
subsequent to an environmental release. Waste Management 10:261-268

10. Tsezos, M. (1985). The selective extration of metals from solution by microorganisms. Candadian Metallurgical Quarterly, 24(2): 141-144.

11. Darpeau, A.J., Laurence. R.A., Harbec. P.S., SaintGennain, G., and Lambert, N.G. (1983). Science et Techniques de I'Eau, 16(4): 359.

12. Tsezos, M., Noh, S.H., and Barid, M.H.I. (1988). A batch reactor transfer kinetic model for immobilized biomass biosorption. Biotechnology and Bioengineering, 32:545-553.

13. Laube, V., Ramamophorthy, S and Kushner, D.J (1979). Mobilization and accumulation of sediment bound heavy metals by algae. Bulletin of Environmental contaminant Toxicology, 21; 763770.

14. Kuyucak, N. and B. Volesky (1990) Biosorption by algal biomass. In: B. Volesky (ed). Biosorption of Heavy Metals. CRC Press, Boca Raton, Florida, USA: 173-198.

15. Strandberg. G.W.. Shumate. S.E. 11, and Parrott. J.r., Jr. (1981). Microbial cells as biosorbents for heavy metals: accumulation of uranium by Saccharamyces cervisea and Pseudomonas aeruginosa. Applied environmental Microbiology, 41: 237-245

16. Norberg, A.B., and Rydin, S. (1984). Development of a continuous process for metal accumulation by Zoogloea ramigera. Biotech nology and Bioengineering, 26:265-268.

17. Brierley, J.a Brierley, L., Decker, R.F. and Goyak, G.M. (1987). Treatment of microorganisms with alkaline solutions to enhance metal uptake properties. U.S. Patent No: 4690894.

18. Brierley, J.A Goyak, G.M., and Brierley, C.L. (1986). Considerations for commercial use of natural products for metal recovery. In Immobilization of ions by biosorption. Edited by H.H. Eccles and S. Hunt, Ellis Horwood, Chichester, United Kingdom, pp. 103-117.

19. Mann, H. (1990) Biosorption of heavy metals by bacterial biomass. In: B. Volesky (ed). Biosorption of Heavy Metals. CRC Press, Boca Raton, Florida, USA: 93-138.

20. Neilands. J.B. (1989). Siderophore systems of bacteria and fungi. In: Metal ions and bacteria. Edited by T.J. Beveridge and R.J. Doyle John Wiley \& sons. New York. Pp. 141-163.

21. Rao, C. R. N., L. Iyengar, and C. Venkobachar (1993) Sorption of copper(II) from aqueous phase by waste biomass. J. Environ. Eng. 119: 369-377.

22. Macaskie, L.E., and Dean, C.R. (1990). Metal sequestering biochemical. In Biosorption of heavy metals. Edited by B. Volesky C.R.C. Press Inc., Boca Raton, Fla.,: 199-248.

23. Beveridge, T.J. (1989). The role of cellular design in bacterial metal accumulation and mineralization. Annual Review of Microbiology, 43: 147-171.

24. Mullen, M.D., Wolf, D.C Ferns. F.O., Beveridge. T.J, Flemming, C.a and Vailey, G.W. (1989). Beacterial sorption of heavy metals. Applied Environmental Microbiology, 55: 129-135.

25. Flemming, C.A., Ferns, F.G., Beveridge. T.J., and Bailey. G.W. (1990). Remobilization of toxic heavy metals adsorbed to bacterial wall-clay composites. Applied Environmental Microbiology, 56; 31913203.

26. Damal, D.W., Greene, B., Henzel, M.T., Hosea, J.M MePherson, R.A., Sneddon, J., and Alexandre. M.D. (1986). Selective recovery of gold and other metal ions from an algal biomass. Environmental Science and Technology, 20(2): 206-210.

27. Ross. I.S., and Townsley, C.C. (1986). The uptake of heavy metals by filamentous fungi. In: Immobilization of ions by biosorption. Edited by H.H. Eccles and S. Hunt Ellis Horwood. Chichester, United Kingdom: 49-58.

28. El Bayaumy, M. A., Bewtra, J. K., Aly, H. I. and Biswas, N. (1997). Biosorption of lead by biomass of sulfate reducing bacteria. Can. J. Civ. Eng. 24.

29. Matheickal, J.T., Iyengar, L., Venkobachar, C., (1991) Sorption and desorption of $\mathrm{Cu}$ (II) by Ganoderma lucidum. Water Pol. Res. J. 26, 187-200.

30. Chang, J.S, Law, R., Chang, C.C., 1997. Biosorption of lead, copper and cadmium by biomass of Pseudomonas Aeruginosa PU21. Water Res. 31, 1651-1658. Chem. Soc. 40: 1361-1368.

31. Harris, P.O., Ramelow, G.J., (1990). Binding of metal ions by particulate biomass derived from Chlorella vulgerris and Scendesmus quadricauda. Environ. Sci. Technol. 24: 220- 228.

32. Matheickal J. T., Yu Q. and Feltham J. (1997) Cu(II) binding by E. radiata biomaterial. Environ. Technol. $18,2-34$

33. Aksu, Z et al., (1992) The biosorption of copper (II) by C. Vulgaris and Zramigera. Environ Technol., 13: 579-586

34. Xing, K., Yang H.S. and Chen M.Y. (2008). Morphological and ultrastructuralcharac-terization of the coelomocytes in Apostichopus japonicus. Aquatic Biology 2:85-92.

35. Langmuir, I. (1916) The adsorption of gases on plane surfaces of glass, mica, and platinum. J. Am. Chem. Soc. 40: 1361-1403.

36. Freundlich H.M.F. (1906). Over the adsorption in solution. J. Phys. Chem. 57: 385-470 